\title{
Rotációs aterectomia alkalmazása krónikus teljes koronária-okklúzió katéteres revaszkularizációjában
}

\author{
Karácsonyi Judit, Nagy Ferenc, Sasi Viktor, Katona András, Ungi Imre
}

Szegedi Tudományegyetem, Általános Orvostudományi Kar, II. sz. Belgyógyászati Klinika és

Kardiológiai Központ, Invazív Kardiológiai Részleg, Szeged

Levelezési cím:

Dr. Karácsonyi Judit, e-mail: judit.karacsonyi8@gmail.com

\begin{abstract}
A krónikus teljes koronária-okklúziók perkután koronária-intervenciója az intervenciós kardiológia dinamikusan fejlődő ága. Új technikák és eszközök megjelenése a sikerráta jelentős növelése mellett a komplikációk számát elfogadható mértéküvé csökkentették e komplex intervenciókban. Az okkludált ér vezetődróttal történő megnyitása a beavatkozás kudarcának leggyakoribb oka, azonban a ballonnal áthatolhatatlan, illetve nem tágítható meszes léziók jelentik az operatőr számára a leginkább frusztráló helyzetet. Ezen léziók kezelésére alkalmazható, legelterjedtebben használt rotablácios technikát mutatjuk be cikkünkben két eseten keresztül. Az első esetünkben korábban sikertelen, ballonnal áthatolhatatlan elzáródást revaszkularizáltunk rotablációval sikeresen anterográd úton, míg második esetünkben ostialis teljes krónikus okklúziót nyitottunk meg retrográd úton anterográd rotablációval kiegészítve. Mindkét esetben sikeres, szövődménymentes rekanalizáció történt, igazolva azt, hogy a rotablációnak krónikus teljes koronária-okklúzióban is fontos szerepe van a meszes léziók hatékony és biztonságos kezelésében.
\end{abstract}

Kulcsszavak: rotabláció, krónikus teljes koronária-okklúzió (CTO)

\section{Use of rotational atherectomy in chronic total occlusion percutaneous revascularization}

Percutaneous revascularization of chronic total occlusions is a fast evolving field of interventional cardiology. Novel techniques and new tools have led to higher procedural success rates accompanied by acceptable risk in these complex interventions. Although failure to cross the lesion with a guide-wire remains the main cause of procedural failure, one of the most frustrating situations after successful intraluminal wiring is presented by balloon uncrossable and/or undilatable lesions mainly due to calcification. In our publication we discuss the most commonly used application to treat such lesions, rotational atherectomy highlighted by two cases. In the first case rotational atherectomy was used successfully for the antegrade recanalization of a balloon uncrossable chronic total occlusion. While in the second case a retrograde wired ostial chronic total occlusion was successfully passed antegrade by using a rotational atherectomy device. Both cases resulted in successful recanalization without any procedural complications, demonstrating the usefulness of rotational atherectomy as an important tool in percutaneous intervention of calcified chronic total occlusions with high success and low complication rates.

Keywords: rotational atherectomy, chronic total occlusion (CTO)

\section{Bevezetés}

A krónikus teljes koronária-okklúziók (CTO) jelenleg erre felkészült intervenciós centrumokban az újabb technikáknak és algoritmusoknak köszönhetően eredményesen és relatíve biztonságosan revaszkularizálhatóak a megfele- lően kiválasztott betegpopulációban (1). A rekanalizáció sikertelenségének leggyakoribb oka, hogy a vezetődrót nem tud keresztülhatolni a lézión. Szintén gyakori probléma a sikeres átjutást követően, hogy a speciális rekanalizáló drót ugyan keresztüljut az adott lézión, de ballon- 
nal, illetve mikrokatéterrel az már nem követhető („,balloon uncrossable lesion") vagy ballonnal sikertelen a szükület előtágítása („,balloon undilatable lesion”) (2). Ezekre az esetekre olyan kezelési algoritmusok, illetve technikák állnak rendelkezésre, amelyek vagy a vezető katéter szupportjának növelésével (katéter extenziós technikák, horgonyzó ballon) vagy a plakk modifikációjával segítenek növelni a penetrációs erőt. A plakk morfológiáját módosító leggyakrabban használt technikák: a plakk irányított disszekciója alacsony átmérőjü ballonokkal (,grenadoplasty"), különböző mikrokatéterek használata, illetve a rotabláció, lézeres angioplasztika és újabban az orbitális atecektomia (3). Jelen cikkünkben e technikák közül a rotációs aterectomiát ismertetjük két eseten keresztül krónikus teljes koronária-okklúzió rekanalizációja során.

\section{Esetismertetés}

1. eset

Az 56 éves férfi beteg kórelőzményében hipertenzió, hyperlipidaemia, 1998-ban konzervatív úton kezelt hátsófali miokardiális infarktus szerepelt. 2015-ben progrediáló, (CCS2-3) effort anginás panaszok miatt kezdődött invazív kivizsgálása. Ekkor koronarográfia során szignifikáns kétér-betegség igazolódott: jó retrográd keringés mellett krónikusan okkludált jobb koronária (CD) és szignifikáns ramus descendens anterior (RDA)-diagonális ág bifurkációs szűkület. Szívsebészeti konzultációt követően a kollaterális keringést szolgáltató RDA szignifikáns szűkületének tágítása történt két gyógyszerkibocsátó stent beültetésével, jó eredménnyel. Perzisztáló panaszok miatt, második ülésben a jobb koszorúér krónikus elzáródásának megnyitási kísérlete következett sikertelen eredménnyel. Ezt követően vettük fel a beteget a Szegedi Tudományegyetem Invazív Kardiológiai Részlegére ismételt rekanalizációs kísérlet céljából. Jobb femoralis artériás punkciót követően Launcher 7F bal Amplatz 1.0 (Medtronic, USA) katéterrel kanüláltuk a jobb koronária-szájadékot. Corsair (Asahi Intecc, Japán) mikrokatéter szupportjával Gaia 2 (Asahi Intecc, Japán) dróttal anterográd irányban a disztális valódi lumenbe jutottunk. A szűkületen sem a mikrokatéterrel, sem alacsony profilú monorail ballonnal nem tudtunk átjutni a lézió proximalitásában végzett előtágítások ellenére. Ezért a Gaia 2 drót által kialakított csatornán keresztül RotaWire Floppy (Boston Scientific, USA) vezetődrótot jutattunk az ér disztális szakaszába és 1,5 mm-es RotaLink Exchangable Burr

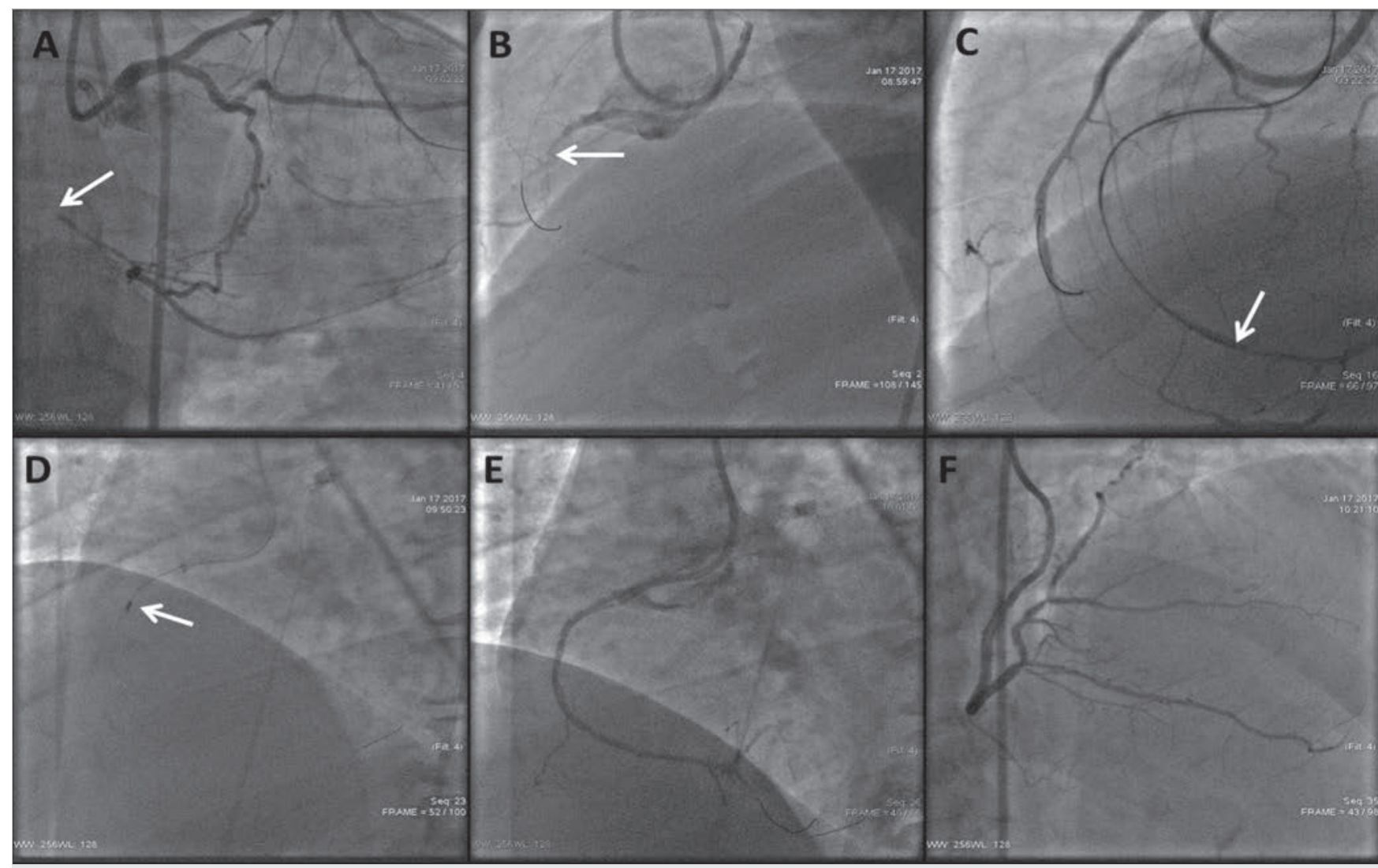

1. ÁBRA. A jobb koszorúér krónikus elzáródásának anterográd megnyitása rotablációval. A: Retrográd töltés, amely magasan visszatelődő elzárt jobb koronáriát ábrázol. A nyíl a disztális sapka magasságát jelöli. B: Ugyanezen nézet anterográd töltéssel. A nyíl a proximális sapkát mutatja. C: Gaia 2 drót (fehér nyíl) a disztális lumenben. D: RotaWire Floppy drót csere után sikeres rotabláció 1,5 mm-es RotaLink Exchangable Burr katéterrel (fehér nyíl). E: Anterográd keringés megindulása rotabláció és további sikeres ballondilatáció után. F: Záró angiográfia stentimplantáció után 
katéterrel (Boston Scientific, USA) a szűkületen átjutva sikeres rotablációt végeztünk. Ezután a ballonkatéterek könnyen átjutottak a lézión, majd előtágítások után a hosszan diffúzan beteg szegmenst összesen $78 \mathrm{~mm}$ gyógyszerkibocsátó stenttel fedtük (1. ábra).

\section{2. eset}

Az 75 éves nőbeteg kórelőzményéből hipertenzió, 2-es típusú diabétesz, 1. stádiumú veseelégtelenség és kétoldali tüdőembolizáció emelendő ki. Nyugalmi fulladás, minimális terhelésre jelentkező angina (CCS3-4) miatt végzett koronarográfia a CD eredésének krónikus teljes okklúzióját igazolta meszes környezetben, elsősorban a ramus circumflexus (Cx) által adott epikardiális kollaterálison keresztül, az ostiumig érő retrográd telődés mellett. Szívultrahang-vizsgálata mérsékelten csökkent balkamra-funkciót mutatott körülírt falmozgászavar nélkül. A fenti kivizsgálást követően vettük fel a beteget rekanalizációs kísérlet céljából intézményünkbe. Jobb femoralis artériás punkciót követően 7F EBU 4 Launcher (Medtronic, USA) katéterrel kanüláltuk a bal koronária-szájadékot. Tekintettel az ostialis okklúzióra retrográd technika mellett döntöttünk. Fielder FC
(Asahi Intecc, Japán) vezetődrótot juttattunk Corsair (Asahi Intecc, Japán) mikrokatéter szupportjával a Cx epikardiális kollaterálison keresztül az okklúzió magasságáig. Az elzáródáson ConfianzaPro 12 (Asahi Intecc, Japán) vezetődróttal jutottunk át retrográd irányban a disztális sapka punkciója után, amelyet követően mind a drótot, mind a mikrokatétert az aortába vezettük. A ConfianzaPro 12 drótot polimerrel burkolt WhisperLS (Abbott, USA) vezetődrótra cseréltünk, majd ezt AndreSnare (Andramed, Németország) lasszó segítségével 7F JR4 Launcher (Medtronic, USA) katéterbe húztuk. Végül, mivel a beavatkozás idején még specializált externalizációs drót nem ált rendelkezésre (RG3, Asahi Intecc, Japán), mikrokatéteren keresztül a drótot RotaWire ES 350 mm-re (Boston Scientific, USA) cseréltük és externalizáltuk. A drót floppy részét steril ollóval elvágtuk majd 1,5 mm-es RotaLink Exchangable Burr katéterrel (Boston Scientific, USA) a meszes ostiumban sikeres rotablációt végeztünk. Ballonos előtágítást követően egy kissé disztálisabban ábrázolódó szignifikáns szúkületet is áthidalva az ostiumig a léziót 2 darab összesen 58 mm hosszú gyógyszerkibocsátó stenttel fedtük (2. ábra).

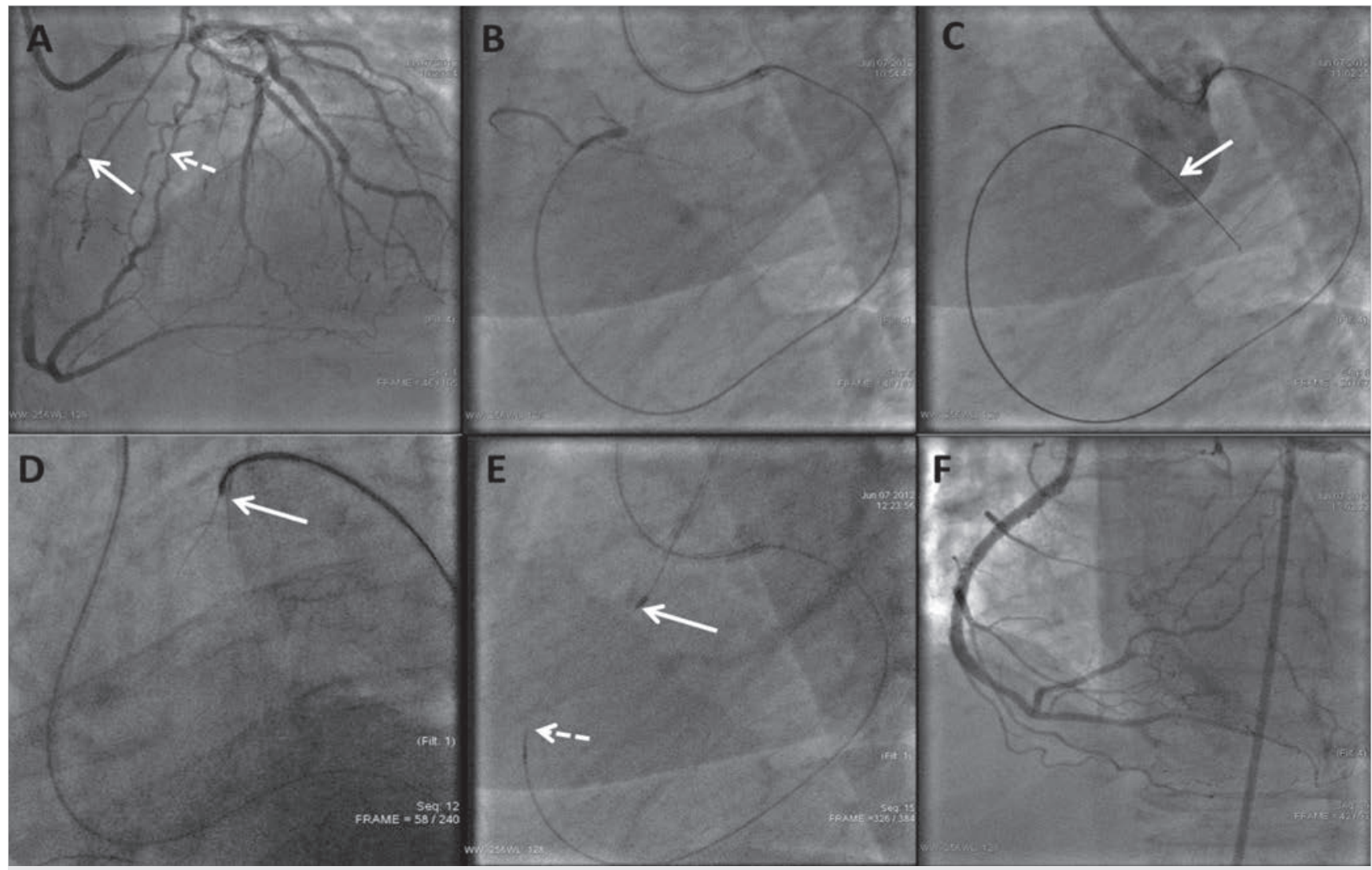

2. ÁBRA. A jobb koszorúér ostialis krónikus elzáródásának retrográd megnyitása rotablációval. A: Retrográd töltés, amely magasan visszatelődő aorto-ostialis pozícióban (fehér nyíl) elzárt jobb koronáriát ábrázol. A fehér szaggatott nyíl a CX epikardiális kollaterálist jelöli. B: Retrográd töltés mikrokatéteren keresztül sikeres retrográd kollaterális átjutást követően. C: Aortába jutás ConfianzaPro (fehér nyíl) vezetődrót. D: WhisperLS vezetődrót-csere majd elfogása AndreSnare lasszóval (fehér nyíl).

E: Mikrokatéteren keresztül RotaWire ES 330 mm csere, majd sikeres anterográd rotabláció 1,5 mm-es RotaLink Exchangable Burr-katéterrel (fehér nyíl) a mikrokatéter visszahúzása után (fehér szaggatott nyíl). F: Záró angiográfia stentimplantáció után 


\section{Megbeszélés}

A bemutatott két esetben, egy anterográd, illetve egy retrográd CTO perkután koronária-intervenciója $(\mathrm{PCl})$ kapcsán szemléltettük a rotabláció jelentőségét. Az extrém meszes lézió ballonnal mindkét esetben áthatolhatatlannak bizonyult. A rotációs aterectomia e speciális alkalmazásáról jelenleg kevés irodalmi adat áll rendelkezésünkre. A ballonnal áthatolhatatlan léziók a CTO kb. 6-9\%-át képezik az egy centrumos, illetve több centrumos vizsgálatok eredményei alapján (2-4). Irodalmi adatok szerint a léziók rezisztenciájának hátterében a léziók komplex morfológiai sajátosságai, a kifejezett meszesedés állhatnak (5). A megoldást többek között a különböző plakkmodifikációs technikák jelenthetik, amelynek egyik tradicionális képviselője a rotablátor.

Pagnotta és munkatársai vizsgálatában 5\%-ban használta a rotablációt CTO PCI-ben (4). Azallini és munkatársai nemrég publikált vizsgálatában 3,5\%-ban alkalmazott rotablációt, az előfordulási arány csökkenése a két vizsgálat között valószínủleg az egyéb technikák és eszközök fejlődésével magyarázható (6). Szegeden a rotablációt 2,9\%-ban alkalmaztuk CTO PCI-ben, relatíve alacsony arány egyik oka ezen eszköz Magyarországi finanszírozásának hiánya.

Technikai háttér: a gyémánttal bevont oliva (burr) 1,25 mm és $2,5 \mathrm{~mm}$ közötti méretekben elérhető, speciális vezetődróton alkalmazandó. Használata során $135000-$ 180 000/perc fordulatszámon mikropartikulumokat ablál a meszes plakk felszínéről, amelyeket a fagocita rendszer távolít el és így a léziót ballonnal átjárhatóvá, tágíthatóvá teszi. Rotabláció során „rotablációs koktél” használata javasolt (verapamil, nitrát, heparin fiziológiás sóoldatban) (7). CTO-ban végzett rotabláció speciális technikai megfontolásai közül kiemelendő a kisméretü 1,25-1,5 mm-es burr választása, az elakadás valószínüségének csökkentésére, hiszen ezen esetekben a plakkmodifikáción és nem a lumen ablációján van a hangsúly. Problémát jelenthet a speciális vezetődrótra történő csere is mikrokatéterrel át nem járható léziók esetén. Ilyen esetekben a lézióba „wedge” pozícióba helyezett mikrokatéteren keresztül a már korábban kialakított csatornán keresztül jó sikeraránnyal tudunk átjutni a speciális vezetődróttal is. Ennek sikertelensége, illetve a pozícióvesztés elkerülésére már eleve alkalmazhatjuk a "RASER” technikát is. Ez a kifejezés a lézer-aterectomia és a rotabláció kombinációját jelenti. E technika alkalmazása során elöször hagyományos CTO-drótra vezetett lézerkatéter (Spectranetics, USA) segíti a mikrokatéter és a rotablációs vezetődrót átjutását az okklúzión, amelyen ezt követően a rotabláció elvégezhető (8). Retrográd CTO megnyitási technika alkalmazása esetén, anterográd drót passzálás kivitelezhetőségének hiányában externalizációt nagyobb nehézségek árán, de magával a RotaWire-rel is végezhetünk lehetőséget teremtve a RotaWire elejének levágását követően az anterográd rotablációra.
A rotabláció számos előnye mellett meg kell említenünk, hogy költségei magasak, a technika elsajátításához speciális tréning és tapasztalat szükséges, illetve, hogy az eszköz csak saját dedikált vezetődrótján alkalmazható. Tapasztalt kézben is előfordulhatnak ritkán potenciálisan súlyos komplikációk: a burr elakadása, AV-blokk, bradycardia, perforáció, disszekció és mikroembolizáció következtében átmenetileg vagy tartósan lassult koronária-áramlás (7). Korábban az ideiglenes pacemaker alkalmazása jobb koronária rotablációja során az európai irányelvek szerint ajánlott volt, azonban jelenleg tapasztalt centrumokban az operatörök ezt ritkán alkalmazzák, mivel a tranziens AV-blokk az esetek jelentős részében spontán vagy gyógyszeresen jól kezelhető. Mindezek mellett irodalmi adatok alapján a rotablációval kombinált CTO-revaszkularizáció szövődményrátája nem magasabb a hagyományos CTO technikákhoz képest (6).

\section{Következtetések}

Összegzésként a teljes krónikus koronária-elzáródások perkután kezelése során újabb és újabb eszközök, technikai megoldások kerülnek elötérbe, azonban fenti két esetünk azt példázza, hogy olyan régi eljárásoknak, mint a rotabláció jelenleg is fontos szerepe lehet a meszes CTO-léziók hatékony és biztonságos kezelésében.

\section{Irodalom}

1. Christopoulos G, Menon RV, Karmpaliotis D, et al. The efficacy and safety of the "hybrid" approach to coronary chronic total occlusions: insights from a contemporary multicenter US registry and comparison with prior studies. J Invasive Cardiol 2014; 26(9): 427-432.

2. Patel SM, Pokala NR, Menon RV, et al. Prevalence and treatment of „balloon-uncrossable” coronary chronic total occlusions. J Invasive Cardiol 2015; 27(2): 78-84.

3. Karacsonyi J, Karmpaliotis D, Alaswad K, et al. Prevalence, indications and management of balloon uncrossable chronic total occlusions: Insights from a contemporary multicenter US registry. Catheter Cardiovasc Interv 2017; 90(1): 12-20

4. Pagnotta $P$, Briguori $C$, Mango $R$, et al. Rotational atherectomy in resistant chronic total occlusions. Catheter Cardiovasc Interv 2010; 76(3): 366-371. doi: 10.1002/ccd.22504

5. Topaz O. СTO revascularization: Obstacles and options in balIoon nonpenetrable lesions. Catheter Cardiovasc Interv 2017; 90(1): 21-22. doi: 10.1002/ccd.27167

6. Azzalini L, Dautov R, Ojeda S, et al. Long-term outcomes of rotational atherectomy for the percutaneous treatment of chronic total occlusions. Catheter Cardiovasc Interv 2017; 89(5): 820-828. doi: $10.1002 /$ ccd. 26829

7. Barbato E, Carrie D, Dardas P, et al. European expert consensus on rotational atherectomy. Eurolntervention 2015; 11(1): 30-36. doi: 10.4244/EIJV11I1A6

8. McKenzie DB, Talwar S, Jokhi PP, et al. How should I treat severe coronary artery calcification when it is not possible to dilate a balIoon or deliver a RotaWire? Eurolntervention 2011; 6(6): 779-783. doi: 10.4244/EIJV6I6A132 